\title{
PENGARUH PEMBELAJARAN INTERAKTIF TERHADAP HASIL BELAJAR TEMATIK SISWA KELAS V DI MI ISLAMIYAH PARENG
}

\author{
Minahul Mubin ${ }^{1}$ \\ Program Studi Madrasah Ibtidaiyah, Universitas Islam Lamongan \\ Email:1minahul.mubin2013@gmail.com
}

\begin{abstract}
This study aims to determine the effect of interactive learning outcomes on classroom students V MI Islamiyah Pareng. This type of research is a quasiexperimental study using nonequivalent control group design conducted with 6 meetings._The subject of this research is class students $V$. .The instrument used was a multiple choice test and observation to capture student learning outcomes and activities that were previously tested to determine the validity and reliability of the test.. Analysis of data using Ttest one right party. The results showed a significant increase in student learning outcomes in learning activities using interactive models.
\end{abstract}

Keywords: Influence, Interactive Learning, Thematic, Learning Outcomes

\section{A. Pendahuluan}

Menelisik perkembangan pendidikan dari masa kemasa, dari kebijakan kementrian pendidikan pada setiap periode menunjukan bahwa Kualitas pendidikan di Indonesia masih rendah masih jauh dari harapan jika kita bandingkan dengan negara negara maju, hal ini disebabkan oleh banyak hal baik dari internal maupun eksternal pemegang kebijakan pendidikan sehingga memunculkan faktor yang mempengaruhinya, faktor di antaranya adalah rendahnya kualitas guru dan rendahnya prestasi siswa. Hal ini berdasarkan pernyataan Widodo dalam kutipan jurnalnya Potret Pendidikan Di Indonesia dan Kesiapannya menghadapi Masyarakat Ekonomi Asia (2015:306). Realitanya adalah layanan pendidikan dan mutu pendidikan di Indonesia masih sangat buruk serta perlu segera dibenahi agar dunia pendidikan di Indonesia tidak semakin terpuruk. Beberapa indikator yang mempengaruhi kualitas pendidikan di Indonesia inilah yang harus dijadikan tolok ukur dalam dunia pendidikan agar segera dibenahi.

Potret pendidikan di Indonesia cukup memprihatinkan. Tiap tanggal 2 Mei selalu diperingati sebagai Hari Pendidikan Nasional. Lalu, bagaimana mutu pendidikan di Indonesia setelah 129 tahun diperjuangkan oleh Ki Hajar Dewantara? Sungguh sulit, dari mana kita memulai diskusi tentang mutu pendidikan? Di era milenial, memang makin banyak orang pintar di negeri ini. Tapi nyatanya, pendidikan seakan makin dikebiri oleh banyak kepentingan. Makin maju bangsa ini, pendidikan makin jadi polemik. Maka, mutu pendidikan pun menjadi taruhannya. Besarnya anggaran 
pendidikan yang mencapai 20\% dari total APBN atau senilai Rp. 419 triliun, harus diakui, tidak berkontribusi signifikan terhadap mutu pendidikan.

Data UNESCO dalam Global Education Monitoring (GEM) Report 2016, mutu pendidikan di Indonesia hanya menempati peringkat ke-10 dari 14 negara berkembang. Sedangkan kualitas guru sebagai komponen penting dalam pendidikan tergolong memprihatinkan, berada di urutan ke-14 dari 14 negara berkembang di dunia.

Mutu pendidikan, masih menjadi soal di Indonesia. Adalah fakta $75 \%$ sekolah di Indonesia tidak memenuhi standar layanan minimal pendidikan. Bahkan kualitas pendidikan Indonesia berada di peringkat 40 dari 40 negara (The Learning Curve, 2014). Belum lagi maraknya kekerasan yang terjadi di sekolah. Berapa banyak siswa yang meregang nyawa akibat kekerasan di dunia pendidikan? Berdasarkan Ikhtisar Eksekutif Strategi Nasional Penghapusan Kekerasan Terhadap Anak 2016-2020 oleh Kemen-PPPA terlihat bahwa $84 \%$ siswa pernah mengalami kekerasan di sekolah dan $50 \%$ anak pernah mengalami perundungan (bullying) di sekolah.

Sementara potret lainnya, sekitar 27 persen pengguna narkoba di Indonesia berasal dari kalangan pelajar dan mahasiswa (Puslitkes UI dan BNN, 2016). Data yang mencengangkan dan mewarnai pendidikan di Indonesia adalah 24 persen mahasiswa dan 23,3 persen pelajar setuju dengan jihad untuk tegaknya negara Islam (Survei BIN, 2017). Pendidikan di Indonesia, boleh dibilang salah arah jika tidak ingin disebut gawat darurat. Mulai dari krisis identitas, krisis tindak kekerasan, hingga krisis kebangsaan menyelimuti langit pendidikan di Indonesia.

Pendidikan nasional tengah mengalami disorientasi. Banyak hal yang harus diubah dan dibenahi dalam pendidikan Indonesia. Pendidikan Indonesia hari ini boleh dibilang pendidikan yang berorientasi pada "tahu sedikit tentang banyak hal, tetapi tidak tahu banyak tentang satu hal."

Mutu Pendidikan sangat mendesak untuk membenahi mutu pendidikan di Indonesia hari ini. Salah satu caranya adalah membenahi kualitas guru. Harus ada langkah serius untuk membenahi kualitas guru. Karena nyatanya, tidak sedikit guru yang hari ini tetap saja menjalankan proses belajar-mengajar dengan pola "top-down".

Guru seolah berada "di atas" dan siswa berada "di bawah", guru bertindak sebagai subjek dan siswa objek belajar. Guru merasa berkuasa untuk "membentuk" siswa. Ibaratnya, guru bertindak sebagai "teko" dan siswa sebagai "gelas" sehingga siswa berstatus hanya menerima apapun yang dituangkan guru. Siswa tidak diajarkan untuk mengeksplorasi kemampuan dirinya; siswa yang disuruh tanpa diajarkan untuk mengenal dirinya.

Guru sering lupa. Belajar bukanlah proses untuk menjadikan siswa sebagai "ahli" pada mata pelajaran tertentu. Siswa lebih membutuhkan 'pengalaman" dalam belajar, bukan "pengetahuan". Karena itu, kompetensi guru menjadi syarat utama tercapainya 
kualitas belajar yang baik. Guru yang kompeten akan meniadakan problematika belajar akibat kurikulum. Kompetensi guru harus berpijak pada kemampuan guru dalam mengajarkan materi pelajaran secara menarik, inovatif, dan kreatif yang mampu membangkitkan gairah siswa dalam belajar.

Mutu pendidikan akan tetap omong kosong. Bila hari ini, guru masih mengajar dengan cara-cara lama. Guru harus mampu mengubah kurikulum menjadi unit pelajaran yang mampu menembus ruang-ruang kelas. Guru tidak butuh kurikulum yang mematikan kreativitas siswa. Seharusnya, guru menjadi sosok yang tidak dominan di dalam kelas. Karena guru bukan pendidik yang berbasis kunci jawaban. Tapi sebagai penuntun siswa agar tahu bidang pelajaran yang paling digemarinya.

Berdasarkan hasil observasi yang dilakukan peneliti di SD 028229 Binjai Barat pada tanggal 26 Januari 2018, hasil belajar tematik siswa di kelas IV masih rendah. 78\% dari 54 siswa masih memperoleh nilai $<70$, 24\% mendapat nilai $>75$. Hal ini menandakan tingkat pengetahuan siswa kelas IV terhadap pembelajaran tematik di kelas masih rendah. Seorang guru yang dijadikan narasumber mengatakan bahwa "Siswa 78\% kurang mengingat materi pembelajaran di kelas. Setelah pembelajaran, mereka tidak lagi mengingat materi yang telah diajarkan." Narasumber juga menambahkan bahwa salah satu kelemahan mereka sebagai guru yaitu kurang inovatif dalam merancang media yang akan digunakan, sehingga hanya memanfaatkan media yang sudah tersedia di kelas untuk kegiatan pembelajaran setiap harinya.

Menurut Kustandi (2011:9) "Media pembelajaran adalah alat yang dapat membantu proses belajar mengajar dan berfungsi untuk memperjelas makna pesan yang disampaikan, sehingga dapat mencapai tujuan pembelajaran dengan lebih baik dan sempurna". Segala sesuatu yang dapat membantu proses belajar mengajar dapat dijadikan media pembelajaran. Pemanfaatan teknologi dalam hal ini merupakan sarana yang mempermudah dalam kelangsungan dunia pendidikan. Teknologi mempermudah penyampaian materi pembelajaran kepada siswa. Memanfaatkan teknologi sebagai alat penunjang pendidikan merupakan upaya dalam meningkatkan keprofesionalan guru dan hasil belajar siswa.

Menurut Simanjuntak (2015: 105-106), "Hasil belajar adalah penguasan mahasiswa pada aspek kognitif, afektif dan psikomotor dengan mengaitkannya penguasaan awal yang telah diterimanya". Untuk mengejar ketertinggalan dunia pendidikan negara Indonesia, perlu adanya upaya untuk meningkatkan hasil belajar siswa dengan melakukan inovasi terhadap kegiatan pembelajaran. Hal inilah yang menarik perhatian peneliti untuk melakukan penelitian ini. Peneliti bermaksud untuk menggunakan model interaktif tematik sebagai wujud penginovasian terhadap model pembelajaran interaktif yang diharapkan dapat meningkatkan hasil belajar siswa kelas $\mathrm{V}$ MI Islamiyah Pareng. 


\section{B. Metode}

Jenis penelitian yang digunakan dalam penelitian ini adalah penelitian quasi experiment dengan menggunakan nonequivalent control group design. Penelitian kuantitatif nonequivalent control group design merupakan penelitian yang membandingkan nilai pretest dan posttest antara kelas eksperimen dan kelas kontrol. Sugiyono (2013:116).

Menurut Mulyatiningsih (2014:9) Populasi adalah sekumpulan orang, hewan, tumbuhan atau benda yang mempunyai karakteristik tertentu yang akan diteliti." Populasi penelitian ini adalah seluruh siswa kelas V MI Islamiyah Pareng yang berjumlah 54 orang siswa.

Mulyatiningsih (2015: 10) mengemukakan bahwa "Sampel adalah Cuplikan atau bagian dari populasi." Arikunto (2010:120) menambahkan "Apabila subjek seorang kurang dari 100 orang, sampel diambil semua. Selanjutnya jika subjeknya lebih dari 100, maka sampel dapat diambil dari antara $10-15 \%$ atau $20-25 \%$ atau lebih." Dengan dasar itu, peneliti menggunakan semua anggota populasi sebagai sampel, yaitu seluruh siswa kelas V MI Islamiyah Pareng sebanyak 54 orang.

Penelitian merupakan kegiatan ilmiah yang sistematis, terarah dan mempunyai suatu tujuan karena kedudukan variabel merupakan hal yang sangat penting, dimana variabel penelitian tersebut mengandung berbagai aspek yang akan diteliti. Dalam penelitian ini terdapat dua macam variabel yaitu :

1. Variabel bebas

Variabel bebas pada penelitian ini adalah pembelajaran model ingteraktif

2. Variabel Terikat

Variabel terikat pada penelitian ini adalah hasil belajar.

Adapun desain penelitian yang digunakan sebagai berikut:

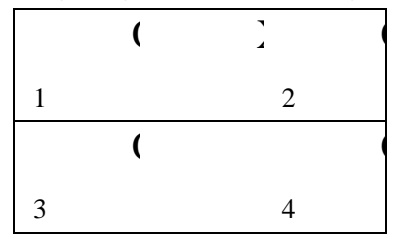

Gambar. Paradigma nonequivalent control group Keterangan:

O1 dan O3 : hasil pengukuran sebelum diberikan perlakuan

$\mathrm{X}$ : perlakuan (treatment)

$\mathrm{O} 2$ : hasil pengukuran setengah kelompok yang diberikan perlakuan

O4 : hasil pengukuran setengah kelompok yang tidak diberi perlakuan

\section{Hasil dan Pembahasan}


Pada proses dalam memperoleh hasil analisis data, peneliti menentukan kelas yang menjadi kelas eksperimen dan kelas kontrol. Kemudian peneliti terlebih dahulu melakukan observasi awal untuk melihat hasil belajar awal siswa pada kedua kelompok sampel.

Pada saat observasi awal (pretest), pencapaian hasil belajar siswa pada kelas eksperimen adalah 53,62dan pada kelas kontrol adalah 54,80, jadi skor hasil belajar awal siswa pada kelas eksperimen dan kelas kontrol hampir sama. Kemudian dilakukan uji perbedaan untuk hasil belajar kognitif siswa dan diperoleh Fhitung $<$ Ftabel atau $0,338<1,952$ maka disimpulkan bahwa kedua sampel memiliki varians yang homogen.

Setelah dilakukan perlakuan yang berbeda yaitu dengan menggunakan pendekatan model interaktif di kelas eksperimen, diperoleh skor pemerolehan hasil belajar siswa di kelas eksperimen adalah 80,86 sedangkan di kelas kontrol adalah 56,60. Dari hasil observasi kedua sampel tersebut diperoleh selisih sebesar 24,26. Dari data yang diperoleh tersebut terdapat perbedaan yang sigifikan antara hasil belajar kognitif siswa pada kelas eksperimen dan kelas kontrol. Ini dapat disebabkan karena pembelajaran dengan model interaktif itu menarik menyenangkan dan siswa terlibat penuh dalam proses pembelajaran.

Maka berdasarkan penelitian yang telah dilakukan di MI Islamiyah Pareng dapat disimpulkan bahwa pembelajaran dengan model interaktif memberi pengaruh positif terhadap hasil belajar kognitif siswa. Hasil penelitian ini juga didukung oleh penelitian penelitian terdahulu yaitu; 1) Hasil penelitian yang dilakukan oleh Wijayanto dan Istianah (2017) dengan judul "Pengaruh Penggunaan Media Game Edukasi Terhadap Hasil Belajar IPA Siswa Kelas IV SDN Kajartengguli Prambon Sidoarjo" diketahui bahwa : Menggunakan metode penelitian eksperimen yang menggunakan teknik analisis data kuantitatif.Teknik pengumpulan data dengan menggunakan tes, yaitu pretest dan posttest. Hasil penelitian menunjukkan rata-rata nilai pretest siswa kelas control 62.85 dan kelas eksperimen 61.24, dan rata-rata nilai posttest pada kelas control 66.48 dan kelas eksperimen 73,93. Dari uji $t$-test diperoleh perbandingan $t$ hitung(2.262) $>t$ tabel (2.002), dan sig. (2-tailed) sebesar 0,027 < 0,05. Dan hasil uji $\mathrm{N}$ gain, diketahui peningkatan hasil tes pada kelas kontrol termasuk kategori rendah sedangkan pada kelas eksperimen termasuk dalam kategori sedang. Dengan demikian dapat disimpulkan bahwa terdapat pengaruh dari penggunaan media game edukasi terhadap hasil belajar IPA siswa kelas IV SDN Kajartengguli Prambon Sidoarjo. Media game edukasi dapat digunakan sebagai pertimbangan penggunaan alternatif media pembelajaran untuk menciptakan suasana kegiatan pembelajaran yang menarik dan menyenangkan.

Hasil penelitian yang dilakukan Agi Ma'ruf Wijaya (2017) yang berjudul "Digital Media Based on Macromadia Flash to increase the Historical Learning Interest of 
Senior HighSchool Students" diketahui bahwa: Berdasarkan hasil dari tes statistik menggunakan program SPSS 20 atas pencapaian pembelajaran, diperoleh nilai 2,324 dengan tingkat signifikan 0,024 lebih kecil dari 0,005 $(0,024<0,025)$, lalu $H O$ ditolak atau ada perbedaan rata-rata di antara kelas eksperimental dan kelas kontrol. Oleh karena itu, pengaruh pengujian pada studi ini berindikasi bahwa kelas eksperimental menggunakan pembelajaran media digital mempunyai tingkat lebih tinggi.

Hasil penelitian dari Iflakhah (2017) dengan judul "Pengaruh Penggunaan Multimedia Interaktif Berbasis Macromedia Flash 8 Dan Motivasi Belajar Terhadap Prestasi Belajar Ips." diketahui bahwa: Menggunakan metode penelitan eksperimen. Berdasarkan hasil analisis diketahui bahwa penggunaan macromedia flash 8 dan motivasi belajar terdapat pengaruh yang signifikan terhadap prestasi belajar IPS siswa MTs Negeri Bangil Kab. Pasuruan. Variabel penggunaan macromedia flash 8 dan motivasi memiliki nilai determinasi yang cukup tinggi terhadap prestasi belajar IPS yaitu sebesar 52,3\%. Hal ini mengindikasikan bahwa variabel bebas dalam penelitian ini merupakan faktor yang sangat penting dalam meningkatkan prestasi belajar IPS siswa MTs Negeri Bangil Kab. Pasuruan. Pengaruh secara simultan antara variabel penggunaan multimedia interaktif macromediaflash 8 dan motivasi belajar terhadap prestasi belajar IPS siswa kelas VII MTs Negeri Bangil Kab. Pasuruan. Hasil analisis data penelitian ini diperoleh hasil sebesar 0,539 dan dapat disimpulkan bahwa penggunaan multimedia interaktif macromedia flash 8 dan motivasi belajar secara simultan ada pengaruh yang signifikan, terhadap prestasi belajar IPS pada siswa kelas VII MTs Negeri Bangil Pasuruan Kab. Pasuruan. Pengaruh variabel macromedia flash 8 terhadap prestasi belajar IPS. Hasil analisis data dari penelitian ini diperoleh hasil sebesar 0,315 dan dapat disimpulkan bahwa penggunaan macromedia flash 8 berpengaruh positif dan signifikan terhadap prestasi belajar IPS siswa MTs Negeri Bangil.

\section{Simpulan}

Berdasarkan hasil penelitian yang diuraikan di atas, maka dapat disimpulkan bahwa terdapat pengaruh positif yang signifikan antara model pembelajaran interaktif dan hasil belajar pelajaran tematik pada siswa kelas V MI Islamiyah Pareng. Hal ini diketahui dari hasil perhitungan posttest pada kelas eksperimen dan kelas kontrol. Pada kelas kontrol diperoleh skor rata-rata 56,60 dan pada kelas eksperimen diperoleh skor rata-rata 80,86. Berdasarkan uji t yang diperoleh thitung> ttabel yaitu 8,512>2,066, dengan demikian Ha diterima, yang menyatakan bahwa terdapat pengaruh signifikan antara model pembelajaran interaktif dan hasil belajar pelajaran tematik pada siswa kelas V MI Islamiyah Pareng. 
Berdasarkan kesimpulan di atas, maka sebagai tindak lanjut penelitian ini disarankan hal-hal sebagai berikut:

1. Bagi siswa, diharapkan siswa harus selalu berperan aktif dalam setiap pelajaran dan kegiatan karena belajar tidak hanya dengan menunggu apa yang disampaikan guru dan menggunakan buku saja namun dengan menggunakan sumber lainnya yang dapat menambah pengetahuan melalui peran aktif dalam pelajaran dan kegiatan apapun disekolah.

2. Bagi guru, lebih sering melakukan inovasi dalam mengajar agar siswa menjadi lebih aktif, bersemangat, termotivasi dalam belajar dan hasil belajar siswa meningkat.

3. Bagi sekolah, untuk meningkatkan kualitas siswa dengan selalu memberikan motivasi kepada siswa agar hasil belajar siswa meningkatserta meningkatkan sarana dan prasarana pembelajaran yang mendukung.

Bagi peneliti selanjutnya, untuk lebih memantapkan hasil penelitian ini. Perlu dilakukan penelitian yang sejenis dengan populasi yang lebih luas dan melibatkan faktor-faktor lain yang hasil belajar siswa serta dengan menggunakan metode pengumpulan data lainnya, sehingga akan diperoleh data yang lebih kompleks.

\section{Daftar Rujukan}

Arsyad, Azhar. 2011. Media Pembelajaran. Jakarta: Rajawali Pers.

Dimyati dan Mudjiono. 2015. Belajar dan Pembelajaran. PT Rineka Cipta, Jakarta.

Fadlillah.2014. Edutainment pendidikan Anak Usia Dini Menciptakan Pembelajaran Menarik, Kreatif, dan Menyenangkan.Jakarta: Penerbit Kencana.

Hamalik, Oemar. 2010. Proses Belajar Mengajar. Jakarta: PT Bumi Aksara.

Iflakhah. 2017. "Pengaruh Penggunaan Multimedia Interaktif Berbasis Macromedia Flash 8 Dan Motivasi Belajar Terhadap Prestasi Belajar Ips (Studi Pada Siswa Kelas Vii Mts Negeri Bangil Kab. Pasuruan)", dalam Jurnal Penelitian dan Pendidikan IPS (JPPI), Vol. 11, (2),hlm 200.

Kemendikbud. 2017. Buku Tematik Terpadu Kurikulum 2013 Buku Siswa SD/MI Kelas IV Tema 4 Berbagai Pekerjaan (Edisi Revisi 2017). Jakarta: Kemendikbud.

Kemendikbud. 2013. Lampiran Permendikbud Nomor 65 Tahun 2013a Tentang Standar Proses Pendidikan Dasar dan Menengah. Jakarta: Kementerian Pendidikan Dan Kebudayaan RI.

Mulyatiningsih, Endang. 2014. Metopel Terapan Bidang Pendidikan. Bandung: Alfabeta

Purwanto. 2008. Evaluasi Hasil Belajar. Yogyakarta: Pustaka Pelajar. 
Simanjuntak, Eva Betty. 2015.Pengaruh Strategi Pembelajaran Dan Motivasi Berprestasi Terhadap Hasil Belajar Penelitian Tindakan Kelas (Ptk) Mahasiswa Pgsd Fip Unimed. School Education Journal Pgsd Fip Unimed . Vol.3, (1).105106.

Slameto. 2010. Belajar dan Faktorfaktor yang Mempengaruhinya. Jakarta: Rineka Cipta.

Sugiyono. 2013. Metode Penelitian Pendidikan. Bandung: Alfabeta. Suprijono, Agus.2010. Cooperative Learning. Yogyakarta. Pustaka Media. 